\title{
Pengaruh Bahan Amelioran dan Pemupukan terhadap Kandungan Hara dan Hasil Padi Lokal Tipe Baru pada Lahan Suboptimal
}

(The Effect of Ameliorant and Fertilization on Nutrient Content and Yield of New Type Local Rice on Suboptimal Land)

\author{
Hendri Gunawan ${ }^{1}$, Helmi ${ }^{1}$, Muyassir ${ }^{1 *}$ \\ ${ }^{1}$ Program Studi Ilmu Tanah, Fakultas Pertanian, Universitas Syiah Kuala \\ *Corresponding author: muyassiramin@gmail.com
}

\begin{abstract}
Abstrak. Tanah suboptimal merupakan lahan yang telah degradasi atau lahan yang mempunyai tingkat kesuburan yang rendah dan tida dapat mendukung perumbuhan tanaman secara optimal. Penelitian ini bertujuan untuk untuk mengetahui efek bahan amelioran dan pemupukan N:P:K terhadap kandungan hara tanah suboptimal dan hasil padi lokal tipe baru dan untuk mendapatkan dosis pupuk N:P:K dan amelioran yang tepat terhadap serapan hara. Penelitian ini menggunakan metode eksperimen dimana perlakuan disusun dalam bentuk Rancangan Acak Kelompok pola Faktorial dan diulang sebanyak 3 kali. Faktor pertama bahan Amelioran yaitu kompos jerami padi dan faktor kedua dosis pupuk Urea, SP-36 dan KCl. Hasil penelitian yang didapat pemupukan N:P:K dapat meningkatkan serapan hara N pada tanaman padi lokal tipe baru (sanbei) dan pada perlakuan pemupukan N, P dan K dengan dosis Urea $300 \mathrm{~kg} / \mathrm{ha}$, SP-36 $150 \mathrm{~kg} / \mathrm{ha}$ dan KCL $90 \mathrm{~kg} / \mathrm{ha}$ dapat meningkatkan serapan hara terhadap jumlah anakan produktif (batan/rumpun), berat gabah total (g/rumpun), berat gabah isi ( $\mathrm{g} /$ rumpun), berat gabah hampa ( $\mathrm{g} /$ rumpun), persentase berat gabah isi (\%), persentase berat gabah hampa (\%), dan potensi tanaman padi Ton/ha. Terdapat interaksi antara amlioran dan pemupukan N:P:K terhadap bobot $100 \mathrm{~g}$ butir gabah tanaman padi lokal tipe baru (sanbei).
\end{abstract}

Kata kunci: Ameliorasi, Pemupukan N:P:K, Lahan Suboptimal, Serapan Hara, Pemupukan, Bobot 1000, Hasil Padi.

\begin{abstract}
Suboptimal soil is land that has been degraded or land that has a low fertility level and cannot support plant growth optimally. This study aimed to determine the effect of ameliorant and N:P:K fertilizer on suboptimal soil nutrient content and yield of new types of local rice and to obtain the right dose of N:P:K and ameliorant fertilizer on nutrient uptake. This study used an experimental method where the treatments were arranged in the form of a factorial randomized block design and repeated 3 times. The first factor is the Ameliorant material, namely rice straw compost and the second factor is the dose of Urea, SP-36 and $\mathrm{KCl}$ fertilizers. The results of the study obtained that N:P:K fertilization could increase $\mathrm{N}$ nutrient uptake in new types of local rice plants (sanbei) and in the treatment of N, P and K fertilization with doses of Urea $300 \mathrm{~kg} / \mathrm{ha}$, SP-36 $150 \mathrm{~kg} / \mathrm{ha}$ and KCL. $90 \mathrm{~kg} / \mathrm{ha}$ can increase nutrient uptake on the number of productive tillers (clump/clump), total grain weight (g/clump), weight of filled grain (g/clump), weight of empty grain (g/clump), percentage of weight of filled grain (\%), the percentage of empty grain weight (\%), and the potential of rice plants Ton/ha. There was an interaction between amliorant and N:P:K fertilization on the weight of $100 \mathrm{~g}$ of grain of new type of local rice plant (sanbei).
\end{abstract}

Keywords: Amelioration, N:P:K Fertilization, Suboptimal Land, Nutrient Uptake, Fertilization, Weight 1000, Rice Yield.

\section{PENDAHULUAN}

Tanah sub-optimum merupakan tanah marginal yang mempunyai potensial yang baik bagi pertanian seperti tanaman hutan, pangan, atau perkebunan. Akan tetapi tanah marginal secara alami tingkat kesuburan terhadap tanah di kategorikan rendah dapat dilihat dari tingkat keasamanya yang tinggi, rendahnya ketersediaan unsur hara, kejenuhan, serta basa-basa yang dipertukarkann rendah (Suharta, 2010)."Di Indonesia lahan marginaI/rusak mudah ditemukan baik pada lahan dalam keadaan basa ataupun kering, pada lahan sulfat masam dan lahan kering berupa tanah ultisoI dengan luas lahan 47,5 juta ha, sementara rawa pasang surut seluas 24 juta ha dan Oxisol 18 juta ha (Suprapto, 2002)." 
Usaha yang dilakukan untuk meningkatkan kualitas tanah marginal yaitu dengan memperbaiki beberapa sifat tanah seperti biologi, kimia ataupun fisika. "Menurut Prasetyo (2006), untuk menungkatkan kualitas tanah marginal/mengalami kerusakan yaitu dengan melakukan ameliorasi dengan cara pemberian bahan organik dan pemupukan.

Bahan amelioran berperan penting dalam hal perbaikan kualitas dan produktivitas tanah pada lahan marginal, namun kelemahan dari bahan amelioran ini rentan terdekomposisi oleh mikroorganisme, sehingga bahan amelioran ini hanya mampu berpengaruh dalam jangka waktu yang singkat. Oleh karna itu penggunaan bahan amelioran yang awalnya sulit terdekomposis dan memiliki berpengaruh dalam jangka singkat kini telah dikembangkan dan mudah didapatkan seperti kulit buah tanaman kakao, biochar/arang, tempurung kelapa dan batang kayu, bahan amelioran yang berasal dari kompos jerami padi atau biochar lebih mudah mempercepat pemulihan terhadap lahan yang mengalami kerusakan atau kekeringan kekeringan terdegradasi yang didominasi fraksi liat (Dariah et al. 2012).

Tanaman padi di Indonesia merupakan makanan pokok bagi masyarakat. Masyarakat Indonesia hampir 90\% mengonsumsi hasil padi yang di olah menjadi beras sebagai makanan utamanya. Sehingga tanaman padi di jadikan usaha tanaman pangan yang menjanjikan di Indonesia. Prayogi (2012). menyatakan, Indonesia pada tahun 2005 menjadi negara ketiga yang memproduksi padi dengan hasil terbanyak setelah Negara India dan Cina dengan nilai sebesar $9 \%$ yaitu mencapai 54 juta ton.

Varietas unggul adalah salah satu komponen faktor produksi yang penting dalam budidaya pertanian di Aceh. Sangat banyak plasma nautfah padi lokal yang mempunyai potensi unggul untuk dapat di budidayakan pada lahan suboptimal. Salah satu varietas lokal tipe baru yang memiliki sifat unggul adalah sanbei yang berasal dari kabupaten Simelue, hasil penelitian yang telah dilakukan terhadap verietas ini dapat berproduksi 3,16 ton/ha (Efendi.,et al) namun demikian penanaman varietas lokal tipe baru pada lahan suboptimal sejauh ini belum ada informasi yang dapat digunakan sebagai dasar dalam pengembangan budidaya padi lokal tipe baru pada sawah suboptimal. Oleh karena itu penelitian ini dilakukan agar pembukaan sawah-sawah baru yang telah dilakukan oleh pemerintah ataupun masyarakat dapat berproduksi secara maksimal sehingga hasil penelitian ini dapat mendukung program pemerintah dalam kebijakan-kebijakan ketahan kedaulatan pangan nasional

\section{METODE PENELITIAN}

Penelitian ini dilaksanakan di Rumah Kasa Fakultas Pertanian Universitas Syiah Kuala. Penelitian berlangsung selama 3 bulan, dilaksanakan dari bulan Maret sampai bulan juli 2019. Tanah sebagai media tanam diambil dari lahan suboptimal di desa Teurebeh Kecamatan Seulimum Kota Jantho.

\section{MATERI DAN METODE}

\section{Amelioran Tanah}

Amelioran atau sering disebut bahan perbaikan tanah yang diberikan ke dalam tanah bertujuan untuk memperbaiki kualitas tanah dan pada bagian perakaran akar pada tanaman. Tujuan diberikan amelioran yaitu sebagai sumber hara bagi tanaman, serta sebagai sumber penjerap atau pengikat kation-kation yang hilang akibat aliran dan menurunkan kemasaman tanah air, serta memperbaiki kualitas tanah yang mengalami kekeringan (Adimihardja dan Sutono 2005). Jenis bahan amelioran sangatlah benyak tersedia dilingkungan petani dan 
bervariasi baik jumlah ataupun jenisnya, antara lain adalah dalam bentuk pupuk kandang, kompos, biochar, arang sekam, kapur, dolomit, gambut dan lain sebagainya.

Penggunaan bahan amelioran pada lahan sub optimal atau lahan marginal sangat berperan penting dalam perbaikan sifat fisika, kimia dan biologi tanah. Peningkatan hasil pada lahan kering dapat dilakukan ameliorasi. Dolomit merupakan bahan amelioran yang sering digunakan sebagai sumber perbaikan pada sifat fisika tanah dan memperbaiki granulasi tanah karena kandungan dolomit terdapat unsur $\mathrm{Mg}$ sebesar 4,03\% dan $\mathrm{Ca}$ sebesar 32,0\%, meningkatkan kejenuhan basa dan menurunkan kepekatan pada ion $\mathrm{H}$, Alumunium, Besi dan Mangan, meningkatkan ketersediaan $\mathrm{Ca}, \mathrm{Mg}, \mathrm{P}$ dan $\mathrm{Mo}$ ini merupakan cara memperbaiki sifat pada kimia tanah, dan sedangkan pada biologi cukup dengan meningkatkan kegiatan jasad renik tanah (Harsono et al. 2011).

\section{Metode Penelitian}

Penelitian ini dilaksanakan di Rumah Kasa Fakultas Pertanian Universitas Syiah Kuala. Penelitian akan berlangsung selama 3 bulan, dilaksanakan dari bulan Maret sampai bulan juli 2019. Tanah sebagai media tanam diambil dari lahan suboptimal di desa Teurebeh Kecamatan Seulimum Kota Jantho

\section{Alat}

Alat yang digunakan dalam penelitian ini adalah paranet, cangkul, timbangan, meteran, karung, tali rafia, ember ukuran 20 liter, pot percobaan 27 unit dan alat tulis, sedangkan alat yang digunakan di laboratorium adalah Oven, Ayakan, Spektrofometer, Tanur timbangan analitik dan alat-alat laboratorium lainnya.

\section{Bahan}

Bahan yang digunakan dalam penelitian ini adalah, Kompos jerami padi, benih padi galur varietas lokal tipe baru yaitu Sanbei yang diperoleh dari Laboratorium Benih Fakultas Pertanian Universitas Syiah Kuala, tanah suboptimal, bahan amelioran, Pupuk $\mathrm{N}, \mathrm{P}_{2} \mathrm{O}_{5}$ dan $\mathrm{K}_{2} \mathrm{O}$ serta beberapa bahan kimia untuk analisis di laboratorium.

\section{Rancangan Percobaan}

Rancangan yang digunakan dalam penelitian ini adalah Rancangan Acak Kelompok pola Faktorial (RAKF). Faktor pertama adalah bahan amelioran kompos jerami dan pupuk lengkap:

Dosis kompos jerami padi (A) yang terdiri dari 3 taraf, yaitu:

$\mathrm{A}_{0}=$ Kontrol

$\mathrm{A}_{1}=15$ ton/ha $76,5 \mathrm{~g} / \mathrm{ember}$

$\mathrm{A}_{2}=30$ ton/ha $153 \mathrm{~g} / \mathrm{ember}$

Faktor kedua adalah pemupukan $(\mathrm{P})$ yang terdiri dari 3 taraf, yaitu:

$\mathrm{P}_{0}=$ Kontrol

$\mathrm{P}_{1}=$ Pupuk N, $\mathrm{P}_{2} \mathrm{O}_{5}$ dan $\mathrm{K}_{2} \mathrm{O} 67,5 \mathrm{~kg}: 27 \mathrm{~kg}: 27 \mathrm{~kg}$

$\mathrm{P}_{2}=$ Pupuk $\mathrm{N}, \mathrm{P}_{2} \mathrm{O}_{5}$ dan $\mathrm{K}_{2} \mathrm{O} 135 \mathrm{~kg}: 54 \mathrm{~kg}: 54 \mathrm{~kg}$

\section{Parameter Pengamatan \\ Sifat Kimia Tanah}

Parameter pengamatan kimia tanah yaitu $\mathrm{pH}, \mathrm{C}$ organik, $\mathrm{N}$ total, $\mathrm{P}$ total dan $\mathrm{K}$ total dapat dilihat pada Tabel 1 . 
Tabel 1. Analisis Sifat Kimia Tanah

$\begin{array}{cc}\text { Sifat Kimia } & \text { Metode } \\ \mathrm{pH} & \text { Elektrometik/ } \mathrm{pH} \text { meter } \\ \mathrm{C}-\text { Organik } & \text { Walkey and Black } \\ \mathrm{N}-\text { Total } & \text { Kjeldhal } \\ \mathrm{P} \text { - Total } & \text { Ekstrak } \mathrm{HCl} 25 \% \\ \mathrm{~K} \text { total } & \text { Ekstraksi } \mathrm{NH}_{4} \mathrm{OA} \mathrm{A}_{\mathrm{CH}} 7\end{array}$

\section{Pertumbuhan}

Parameter pengamatan pertumbuhan yaitu:

a. Tinggi tanaman $(\mathrm{cm})$

Pengamatan tinggi tanaman diukur dari pangkal batang sampai pada ujung daun terpanjang. Pengukuran tinggi tanaman dilakukan 30, 60, 45 dan 90 hari setelah tanam (HST). b. Berat berangkasan basah dan kering

Berangkasan basah yaitu bagian leher akar hingga ujung akar yang masih segar dengan satuan gram. Sedangkan Berat berangkasan kering tanaman padi dikeringkan anginkan setelah pemanenan, lalu berangkasan dikeringkan menggunakan oven dengan suhu $70^{\circ} \mathrm{C}$ selama $2 \times 24$ jam. Berangkasan yang sudah kering diukur dengan timbangan analitik dengan satuan gram. c. Jumlah anakan $15,30,45,60$, dan 90 HST dihitung dengan cara menghitung satu per satu.

\section{Hasil}

a. Jumlah malai per rumpun

b. Persentase gabah bernas per rumpun $(\%)$

c. Persentase gabah hampa per rumpun $(\%)$

d. Bobot 1000 butir gabah (g)

\section{Analisa Data}

Dari dua faktor tersebut, diperoleh 9 kombinasi perlakuan dan masing-masing perlakuan diulang tiga kali sehingga didapati 27 satuan unit percobaan.

\section{HASIL DAN PEMBAHASAN}

\section{Analisis Sifat Kimia Tanah Awal}

Hasil analisis tanah Ultisol yang dilakukan di Laboratorium Penelitian Tanah dan Tanaman Fakultas Pertanian Universitas Syiah Kuala disajikan pada Tabel 3.

Tabel 3. Hasil Analisis Tanah Awal Pengaruh Bahan Amelioran dan Pemupukan Terhadap Kandungan Hara dan Hasil Padi Lokal Tipe Baru pada Lahan Suboptimal

\begin{tabular}{|c|c|c|c|}
\hline No & Analisis Kimia Tanah & Nilai & Kriteria \\
\hline 1 & $\mathrm{pH} \mathrm{H} \mathrm{H}_{2} \mathrm{O}$ & 5,67 & Agak Masam \\
\hline 2 & C- Organik (\%) & 0,69 & Sangat Rendah \\
\hline 3 & N- Total $(\%)$ & 0,05 & Sangat Rendah \\
\hline 4 & P- Total (\%) & 0,06 & Sangat Rendah \\
\hline 5. & P- Tersedia $\left(\mathrm{mg} / \mathrm{kg}^{-1}\right)$ & 0,90 & Sangat Rendah \\
\hline 6 & $\mathrm{~K}-\mathrm{dd}(\mathrm{cmol} / \mathrm{kg})$ & 0,20 & Rendah \\
\hline 7 & $\mathrm{KTK}(\mathrm{cmol} / \mathrm{kg})$ & 14,80 & Rendah \\
\hline 8 & $\mathrm{~KB}(\%)$ & 25,34 & Rendah \\
\hline
\end{tabular}


Tabel 3 hasil analisis karakteristik tanah yang didapat menunjukkan bahwa sifat kimia tanah yang digunakan memiliki $\mathrm{pH}$ yang tergolong agak masam karena berada pada rentang 5,5 sampai 6, Kandungan C-organik, N-total, P-total dan P-tersedia tergolong sangat rendah, sementara itu untuk nilai K-dd, KTK dan KB tergolong rendah. Berdasarkan hasil analisis karakteristik tanah yang telah dilakukan, sampel tanah memiliki tingkat kesuburan yang rendah. Kemasaman dan kualitas tanah yang rendah sering terjadi pada tanah ultisol, kandungan bahan organik yang rendah dan nutrisi makro rendah sehingga tanah ini belum dapat dimanfaatkan secara maksimal.

Menurut Fitrianti et al (2014), menyatakan bahwa tanah Ultisol memiliki masaIah keasaman tanah, yaitu unsur hara yang cukup rendah dan nutrisi makro rendah serta memiliki ketersediaan $\mathrm{P}$ yang tergolong sangat rendah. Kandungan $\mathrm{Al}$ dan fiksasi $\mathrm{P}$ tinggi, kandungan unsur Fe dan Mn yang tinggi dapat meracuni tanaman sehingga tanaman sulit berkembang serta kapasitas tukar kation, C-organik rendah dan kejenuhan basa, Tingginya curah hujan disebagian wilayah Indonesia menyebabkan tercucinya unsur hara basa dalam tanah menjadi bereaksi masam dengan kejenuhan basa rendah (Mulyani dkk, 2010).

\section{Serapan Hara N Akibat Pemberian Pupuk dan Amelioran pada Tanah Suboptimal}

Hasil penelitian menunjukkan bahwa rata-rata serapan hara $\mathrm{N}$ berpengaruh nyata akibat pemberian pupuk N:P:K dan amelioran terhadap tanaman padi pada tanah sawah suboptimal.

Tabel 4. Rata-rata serapan hara N akibat pemberian pupuk N:P:K dan amelioran

\begin{tabular}{|c|c|c|c|c|}
\hline \multirow{3}{*}{$\begin{array}{c}\text { Pupuk (kg/ha) } \\
\text { (Urea:SP-36:KCl) }\end{array}$} & \multicolumn{3}{|c|}{ Amelioran (ton/ha) } & \multirow{3}{*}{ Rata-Rata } \\
\hline & 0 & 15 & 30 & \\
\hline & \multicolumn{3}{|c|}{$\ldots \ldots \ldots \ldots \ldots \ldots \ldots \ldots \ldots \ldots \% \ldots \ldots \ldots \ldots \ldots \ldots \ldots \ldots \ldots$} & \\
\hline 0:0:0 & 12,76 & 28,29 & 24,84 & $21,97 \mathrm{c}$ \\
\hline $150: 75: 45$ & 47,49 & 58,22 & 68,51 & $58,07 \mathrm{~b}$ \\
\hline $300: 150: 90$ & 68,53 & 43,20 & 137,71 & 83,15 a \\
\hline Rata-rata & 42,93 & 43,24 & 77,02 & \\
\hline
\end{tabular}

Keterangan: Angka yang diikuti oleh huruf yang sama pada kolom yang sama tidak berbeda nyata pada (DMRT $0,05=83,28$ 58,21 22,11 Pemupukan)

Tabel 4 menunjukkan bahwa serapan hara $\mathrm{N}$ akibat pemberian pupuk dan amelioran pada lahan sawah suboptimal tergolong sama pada setiap perlakuan. Nilai rata-rata serapan hara $\mathrm{N}$ akibat pemberian amelioran dan pupuk N:P:K berkisar antara 21,97 sampai 83,15 persen. Nilai rata-rata tertinggi terdapat pada pemberian kompos jerami padi dengan perlakuan 300:150:90 yaitu 83,15. Hal ini di diduga pemberian pupuk N:P:K dapat memenuhi unsur hara yang dibutuhkan oleh tanaman sehingga berpengaruh nyata terhadap serapan hara $\mathrm{N}$, sependapat dengan Englestad (1997) menyatakan bahwa pentingnya pemberian pupuk N yang optimal untuk pertumbuhan dan perkembangan tanaman. Menurut Iswahyudi et al., (2018) penggunaan pupuk N:P:K dapat membantu meningkatakan unsur hara dalam jumlah besar ke dalam tanah, sehingga dengan pemberlan pupuk dalam dosis yang tepat dapat mensuplai peningkatan pada potensi hasil dan perkembangan tanaman padi tanaman.

\section{Hasil}

Hasil penelitian menunjukkan bahwa rata-rata hasil pemupukan berpengaruh nyata akibat pemberian pupuk N:P:K dan amelioran terhadap tanaman padi pada tanah sawah suboptimal. 
Tabel 5. Rata-rata jumlah anakan produktif tanaman padi akibat pemberian pupuk N:P:K

\begin{tabular}{|c|c|c|c|c|}
\hline \multirow{3}{*}{$\begin{array}{l}\text { Pupuk (kg/ha) } \\
\text { (Urea:SP-36:KCl) }\end{array}$} & & oran & & \multirow{3}{*}{ Rata-rata } \\
\hline & 0 & 15 & 30 & \\
\hline & \multicolumn{3}{|c|}{.................batang/rumpun.............. } & \\
\hline 0:0:0 & 6 & 10 & 12 & $10 \mathrm{a}$ \\
\hline $150: 75: 45$ & 19 & 18 & 21 & $19 \mathrm{~b}$ \\
\hline $300: 150: 90$ & 29 & 33 & 34 & $32 \mathrm{c}$ \\
\hline
\end{tabular}

Keterangan : Angka yang diikuti oleh huruf yang sama pada kolom berbeda nyata pada $\left(\mathrm{DMRT}_{0,05}=3,553_{3,72} 3,83\right.$ Pemupukan)

Tabel 6. Rata-rata berat gabah total akibat pemberian pupuk N:P:K dan amelioran pada tanah suboptimal

\begin{tabular}{|c|c|c|c|c|}
\hline \multirow{3}{*}{$\begin{array}{c}\text { Pupuk (kg/ha) } \\
\text { (Urea:SP-36:KCl) }\end{array}$} & \multicolumn{3}{|c|}{ Amelioran (ton/ha) } & \multirow{3}{*}{ Rata-rata } \\
\hline & 0 & 15 & 30 & \\
\hline & \multicolumn{3}{|c|}{$\ldots \ldots \ldots \ldots \ldots \ldots \ldots g$ /rumpun $\ldots \ldots \ldots \ldots \ldots \ldots \ldots$} & \\
\hline 0:0:0 & 17.40 & 37.53 & 62.53 & $39.15 \mathrm{a}$ \\
\hline $150: 75: 45$ & 64.07 & 73.65 & 71.10 & $69.60 \mathrm{~b}$ \\
\hline $300: 150: 90$ & 97.86 & 108.45 & 105.82 & $104.04 \mathrm{c}$ \\
\hline Rata-Rata & $59.77 \mathrm{~A}$ & $73.21 \mathrm{~B}$ & $79.81 \mathrm{C}$ & \\
\hline
\end{tabular}

Keterangan : Angka yang diikuti oleh huruf yang sama pada kolom dan Baris berbeda tidak nyata pada (DMRT $0,05=12,44$ 13,05 13,43 Pemupukan dan Amelioran).

Tabel 7. Rata-rata berat gabah isi akibat pemberian pupuk N:P:K dan amelioran pada tanah suboptimal

\begin{tabular}{|c|c|c|c|c|}
\hline \multirow{3}{*}{$\begin{array}{l}\text { Pupuk (kg/ha) } \\
\text { (Urea:SP-36:KCl) }\end{array}$} & \multicolumn{3}{|c|}{ Amelioran (ton/ha) } & \multirow{3}{*}{ Rata-rata } \\
\hline & 0 & 15 & 30 & \\
\hline & \multicolumn{3}{|c|}{. $\ldots \ldots \ldots \ldots \ldots \ldots \ldots . \mathrm{g} /$ rumpun.$\ldots \ldots \ldots \ldots \ldots \ldots \ldots$} & \\
\hline $0: 0: 0$ & 12,77 & 19,97 & 36,89 & $23,21 \mathrm{a}$ \\
\hline $150: 75: 45$ & 46,25 & 54,83 & 49,19 & $50,09 \mathrm{~b}$ \\
\hline 300:150:90 & 77,74 & 79,68 & 85,60 & $81,01 \mathrm{c}$ \\
\hline
\end{tabular}

Keterangan : Angka yang diikuti oleh huruf yang sama pada kolom yang sama tidak berbeda nyata pada DMRT $_{0,05}=10,91$ 11,44 11,78 Pemupukan)

Tabel 8. Rata-rata bobot 100 butir gabah akibat pemberian pupuk N:P:K dan amelioran pada tanah suboptimal

\begin{tabular}{cccc}
\hline \multirow{2}{*}{\begin{tabular}{c} 
Pupuk $(\mathrm{kg} / \mathrm{ha})$ \\
\cline { 2 - 4 }$($ Urea:SP-36:KCl)
\end{tabular}} & \multicolumn{3}{c}{ Amelioran (ton/ha) } \\
\cline { 2 - 4 } & \multicolumn{2}{c}{$\ldots \ldots \ldots \ldots \ldots \ldots \ldots \ldots \ldots \ldots \ldots \ldots \ldots \ldots \ldots \ldots \ldots \ldots \ldots \ldots \ldots$} \\
\hline $0: 0: 0$ & $2,44 \mathrm{a}$ & $2,62 \mathrm{a}$ & $2,62 \mathrm{a}$ \\
& $\mathrm{A}$ & $\mathrm{A}$ & $\mathrm{A}$ \\
$150: 75: 45$ & $2,76 \mathrm{ab}$ & $2,59 \mathrm{ab}$ & $2,61 \mathrm{ab}$ \\
& $\mathrm{AB}$ & $\mathrm{AB}$ & $\mathrm{AB}$ \\
$300: 150: 90$ & $2,56 \mathrm{~b}$ & $2,73 \mathrm{~b}$ & $2,70 \mathrm{~b}$ \\
& $\mathrm{~B}$ & $\mathrm{~B}$ & $\mathrm{~B}$
\end{tabular}

Keterangan : Angka yang diikuti oleh huruf yang sama berbeda tidak nyata, huruf kecil d baca horizontal huruf besar d baca vertikal pada (DMRT $0,05=0,330,350,36$ Interaksi)

Tabel 5 menunjukkan bahwa pemberian pupuk N:P:K menghasilkan anakan produktif padi sanbei berkisar antara 10 sampai 32 batang/rumpun. Rata-rata jumlah anakan tertinggi di jumpai pada dosis pemupupukan 300:150:90 kg/ha, yaitu 32 batang/rumpun yang berbeda nyata dengan semua dosis pemupukan lainya. Hal ini di duga adanya ketersediaan hara dalam jumlah yang cukup dari pupuk yang diberikan pada sawah suboptimal. Sejalan dengan pendapat Dobermann dan Fairhust, 2000, hara N mudah terserap sehingga dapat memudahkan proses perkembangan tanaman, jumlah anakan, tinggi tanaman, memperbesar ukuran daun dan besar buah serta memperbaiki kualitas tanah, meningkatkan jumlah gabah, menambah 
kadar protein beras dan persentase jumlah gabah isi, dan menyediakan bahan makanan bagi mikrobia. Tanaman yang memiliki sifat gen yang baik dan lingkungan yang sesuai (diinginkan) oleh tanaman akan meningkatkan jumlah anakan (Husana, 2010; Anhar et al. 2016).

Tabel 9. Rata-rata hasil padi lokal tipe baru akibat pemberian pupuk dan amelioran pada tanah suboptimal

\begin{tabular}{|c|c|c|c|c|}
\hline \multirow{3}{*}{$\begin{array}{c}\text { Pupuk (kg/ha) } \\
\text { (Urea:SP-36:KCl) }\end{array}$} & \multicolumn{3}{|c|}{ Amelioran (ton/ha) } & \multirow{3}{*}{ Rata-rat: } \\
\hline & 0 & 15 & 30 & \\
\hline & \multicolumn{3}{|c|}{..................ton/ha.................... } & \\
\hline $0: 0: 0$ & 1,04 & 1,63 & 3,01 & $1,89 \mathrm{a}$ \\
\hline $150: 75: 45$ & 3,78 & 4,48 & 4,02 & $4,09 \mathrm{~b}$ \\
\hline $300: 150: 90$ & 6,35 & 6,50 & 6,99 & $6,61 \mathrm{c}$ \\
\hline Rata-rata & 3,72 & 4,20 & 4,67 & \\
\hline
\end{tabular}

Keterangan : Angka yang diikuti oleh huruf yang sama pada kolom tidak berbeda nyata pada (DMRT $0,05=2,744,98$ dan 7,53 Pemupukan).

Pada Tabel 6 menunjukkan rata-rata berat gabah total padi lokal tipe baru akibat pemberian pupuk N:P:K berkisaran antara 39,15 sampai dengan 104,04 g/rumpun. Rata-rata berat gabah total teringgi di jumpai pada pemberian pupuk $\mathrm{N}, \mathrm{P}, \mathrm{K}$ dengan dosis 300:150:90 $\mathrm{kg} / \mathrm{ha}$ yaitu 104,04 g/rumpun yang berbeda nyata dengan dosis pemupukan lainya. Hal ini di duga adanya ketersediaan hara yang lengkap dalam jumlah mencukupi dari pupuk N:P:K yang diberikan pada sawah suboptimal. Adanya pengaruh nyata pada berat Gabah per plot, pupuk $\mathrm{N}: \mathrm{P}: \mathrm{K}$ dapat meningkatkan proses fisiologi berakibat berat gabah dan hasil produksi tanaman padi meningkat, Hal ini sesuai dengan pernyataan Faisal (2014) penetapan dosis dalam pemupukan sangat penting dilakukan karena dapat terganggunya pertumbuhan jika tidak sesuai dengan dosis yang di butuhkan tanaman.

Pada Tabel 7 menunjukkan bahwa rata-rata berat gabah isi padi lokal tipe baru akibat pemberian pupuk N:P:K berkisar antara 23,21 sampai 81,01 g/rumpun. Rata-rata berat gabah isi tertinggi di jumpai pada pemberian pupuk N:P:K dengan pemberian dosis 300:150:90 $\mathrm{kg} / \mathrm{ha}$ yaitu dengan nilai 81,01 g/rumpun yang bereda nyata dengan pemberian dosis pemupukan lainya. Rata-rata gabah isi tanaman padi sanbei ternyata dapat meningkat seiring meningkatnya pupuk N:P:K yang diberikan. Sehingga diperkirakan ketersediaan hara N:P:K berada dalam jumlah yang mencukupi kebutuhan tanaman. Purnomo (2009) menyatakan bahwa pemberian pupuk N:P:K baik majemuk maupun tunggal dapat meningkatkan jumlah maIai dan bobot malai dibandingkan tanpa pemberian N:P:K.

Tabel 8 menunjukkan Rata-rata bobot 100 butir gabah padi lokal tipe baru (sanbei) tertinggi pada pemupukan berkisar antara 2,76 sampai 2,44 g. Nilai bobot 100 butir gabah terendah di jumpai pada perlakuan dosis 150:75:45 kg/ha. Bobot 100 butir gabah pada perlakuan 150:75:45 kg/ha, berbeda nyata dengan semua perlakuan lainya. Hal ini di duga karena pemberian pupuk N:P:K dan amelioran terhadap bobot 100 butir gabah tanaman padi sudah tercukupi, sesuai dengan penyataan Krismawati (2007) berpendapat bahwa meningkatnya potensi hasil tanaman padi pada bobot 1000 butir di pengaruhi oleh ketersediaan unsur hara N:P:K, rata-rata bobot 100 butir gabah (g/butir) pada pemberian amelioran berkisar antara 2,76 sampai dapat di liat pada tabel di atas Gabah isi dan berat 1000 butir varietas Sanbei.

Tabel 9 menunjukkan rata-rata hasil tanaman padi per hektar akibat perlakuan pemupukan N:P:K berkisar antara 1,89 ton/ha sampai dengan 6,61 Ton/ha. Rata-rata hasil tanaman padi per hektar tertinggi dijumpai pada perlakuan dengan dosis 300:150:90 kg/ha 
yaitu dengan nilai 6,61 ton/ha dan berbeda nyata dengan semua pemupukan lainya. Hal ini karena ketersediaan unsur hara yang cukup dan dapat diserap dengan cepat bagi tanaman tetapi tidak terlepas dari pengaruh bahan organik yang memiliki unsur hara mikro dalam membantu proses pertumbuhan dan penyerapan unsur hara secara optimal dan efektif. Menurut Nyanjang (2003) pertumbuhan dan hasil tanaman padi di pengaruhi oleh pemupukan yang lengkap dan pemberian dosis yang tepat dapat menggantikan unsur hara yang hilang atau tercuci pada tanah. Hal ini sependapat dengan Sutejo (2002) bahwa pemberian pupuk kimia (anorganik) ke dalam tanah dapat menggantikan unsur hara yang hilang dan dapat menambah ketersediaan hara yang cepat untuk tanaman.

Hasil penelitian menunjukkan bahwa rata-rata hasil pemupukan berpengaruh tidak nyata akibat pemberian pupuk N:P:K dan amelioran terhadap tanaman padi pada tanah sawah suboptimal.

Tabel 10. Rata-rata berat gabah hampa akibat pemberian pupuk N:P:K dan amelioran pada tanah suboptimal

\begin{tabular}{|c|c|c|c|c|}
\hline \multirow{3}{*}{$\begin{array}{c}\text { Pupuk (kg/ha) } \\
\text { (Urea:SP-36:KCl) }\end{array}$} & \multicolumn{3}{|c|}{ Amelioran (ton/ha) } & \multirow{3}{*}{ Rata-rata } \\
\hline & 0 & 15 & 30 & \\
\hline & \multicolumn{3}{|c|}{ 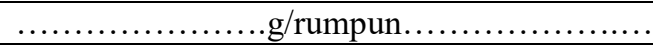 } & \\
\hline $0: 0: 0$ & 3.96 & 14.23 & 25.62 & 14.60 \\
\hline $150: 75: 45$ & 17.81 & 18.72 & 21.60 & 19.38 \\
\hline 300:150:90 & 21.21 & 28.77 & 22.75 & 24.25 \\
\hline Rata-rata & 14.33 & 20.57 & 23.32 & \\
\hline
\end{tabular}

Tabel 11. Rata-rata persentase berat gabah isi akibat pemberian pupuk N:P:K dan amelioran pada tanah suboptimal

\begin{tabular}{|c|c|c|c|c|}
\hline \multirow{3}{*}{$\begin{array}{c}\text { Pupuk (kg/ha) } \\
\text { (Urea:SP-36:KCl) }\end{array}$} & \multicolumn{3}{|c|}{ Amelioran (ton/ha) } & \multirow{3}{*}{ Rata-rata } \\
\hline & 0 & 15 & 30 & \\
\hline & \multicolumn{3}{|c|}{ 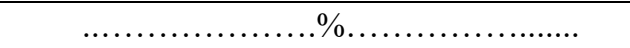 } & \\
\hline $0: 0: 0$ & 26.48 & 33.12 & 39.22 & 32.94 \\
\hline $150: 75: 45$ & 28.06 & 37.88 & 30.74 & 32.23 \\
\hline 300:150:90 & 39.01 & 21.08 & 11.68 & 24.16 \\
\hline Rata-rata & 31.18 & 30.93 & 27.21 & \\
\hline
\end{tabular}

Tabel 12. Rata-rata persentase gabah hampa akibat pemberian pupuk dan amelioran pada tanah suboptimal

\begin{tabular}{|c|c|c|c|c|}
\hline \multirow{3}{*}{$\begin{array}{l}\text { Pupuk (kg/ha) } \\
\text { (Urea:SP-36:KCl) }\end{array}$} & \multicolumn{3}{|c|}{ Amelioran (ton/ha) } & \multirow{3}{*}{ Rata-rata } \\
\hline & 0 & 15 & 30 & \\
\hline & \multicolumn{3}{|c|}{ $\ldots \ldots \ldots \ldots \ldots \ldots \ldots \% \ldots \ldots \ldots \ldots \ldots \ldots \ldots$} & \\
\hline $0: 0: 0$ & 73.52 & 66.88 & 60.78 & 67.06 \\
\hline $150: 75: 45$ & 71.94 & 62.12 & 69.26 & 67.77 \\
\hline $300: 150: 90$ & 60.99 & 78.20 & 88.32 & 75.84 \\
\hline Rata-rata & 68.82 & 69.07 & 72.79 & \\
\hline
\end{tabular}

Tabel 8 menunjukkan bahwa rata-rata tertinggi berat gabah hampa padi lokal tipe baru akibat pemberian pupuk N:P:K berkisaran antara 23,32 sampai 14,33 g/rumpun. Hal ini diduga karena pemberian ameliorasi dan pemupukan $\mathrm{N}: \mathrm{P}: \mathrm{K}$ belum tercukupi sehingga tidak dapat memenuhi unsur hara yang dibutuhan oleh tanaman, sehingga tidak berpengaruh nyata terhadap persentase jumlah gabah hampa per rumpun. Hal ini di duga karena pemberian pupuk N:P:K dan amelioran terhadap berat gabah hampa tanamapan padi belum cukup terpenuhi, sehingga tidak berpengaruh nyata. Waty et al (2014) mengatakan bahwa dengan 
unsur hara yang cukup pada tanaman dapat meningkatkan tingkat produksi tanaman padi dan mengurangi persentase gabah hampa malai.

Tabel 9 menunjukkan rata-rata persentase berat gabah isi tanaman padi loka tipe baru tertinggi berkisar antara 32,94 sampai 24,16 \%. Hal ini diduga karena pengaruh kandungan unsur hara pada tanah yang digunakan sangat rendah sehingga perlakuan ameliorasi dan pemupukan tidak dapat memenuhi unsur hara yang dibutuhan oleh tanaman, meskipun tidak memberikan pengaruh yang nyata, pada pemberian amelioran dan pemupukan $\mathrm{N}, \mathrm{P}$ dan $\mathrm{K}$ mampu meningkatkan jumlah persentase gabah isi. Lita (2013) berpendapat bahwa jumlah malai merupakan salah satu indikator produksi tanaman.

Tabel 10 menunjukkan rata-rata persentase berat gabah hampa padi lokal tipe baru tertinggi berkisar antara 75,84 sampai 67,06 \%. Hal ini di duga karena pemberian pupuk $\mathrm{N}: \mathrm{P}: \mathrm{K}$ dan amelioran terhadap persentase gabah hampa tanaman padi lokal tipe baru belum tercukupi sehingga tidak berpengaruh nyata. Verdiana et al, (2016) menyatakan kompos jerami padi dapat memperbaiki kualitas tanah dan meningkatkan persentase hasil tanaman padi, sehingga penambahan biochar dalam tanah mampu meningkatkan unsur hara dan menggantikan hara yang hilang dalam akar tanaman mampu menjerap serapan hara.

\section{KESIMPULAN}

1. Bahan amelioran berupa kompos jerami padi dapat meningkatkan kandungan hara $\mathrm{N}$ Total pada padi lokal tipe baru pada sawah suboptimal.

2. Pemupukan N:P:K dapat meningkatkan hasil padi tipe baru (sanbei) yang ditanam pada sawah suboptimal.

\section{DAFTAR PUSTAKA}

Aak. 1990. Budidaya Tanaman Padi. Kanisius: Yogyakarta. Hal: 172.

Abdullah, B., S. Cokrowidjojo \& Sularjo. 2008. Perkembangan dan Prospek Perakitan Padi Tipe Baru di Indonesia. J. Litbang Pertanian. 27 (1): 1-9.

Abdullah, B., S. Tjokrowidjojo, B. Kustianto, dan A.A. Daradjat. 2005. Pembentukan varietas unggul tipe baru Fatmawati. Penelitian Pertanian.

Adimihardja A, Sutono S. 2005. Teknologi pengendalian erosi lahan berlerang. Dalam: Marham (eds): Prosiding Teknologi Pengelolaan Lahan Kering Menuju Petanian Produktif dan Ramah Lingkungan. Pusat Penelitian dan Pengembangan Tanah dan Agroklimat Bogor. 4-5 Juni 2005.

Alvaro-Fuentes, J., M.V. Lopez, C. Cantero- Martinez, and J.L. Arrue. 2008. Tillage effects on soil organic carbon fractions in mediterranean dryland agroecosystems. Soil Sci. Soc. Am. J. 72(2): 541-547.

Anda, M., N. Suharta, and S. Ritung. 2000. Development of soils derived from weathered sedimentary, granitic and ultrabasic rocks in South Kalimantan Province: I. Mineralogical composisition and chemical properties. Jurnal Tanah dan Iklim 18: 1- 10.

Aryanti, E., Yulita, Rani, A., \& Annisava. (2016). Pemberian Beberapa Amelioran Terhadap Perubahan Sifat Kimia Tanah Gambut. Jurnal Agroteknologi,

Bakhtiar B, Kesumawati E, Hidayat T. 2011, Karakteristik Plasma Nutfat Aceh Untuk Perakitan Varietas Adatif Pada Tanah Masam. Darussalam. The Faculty Of Agriculture, Syiah Kuala. 
Bakhtiar, Kesumawati E, Hidayat T dan Rahmawati M. 2011. Karakterisasi plasma nutfah padi lokal Aceh. Agrista. 15 (3): 79-86.

Balai Penelitian dan Pembangan Pertanian. 2009. Biochar Penyelamat Lingkungan. Balai Penelitian Tanaman Padi. Sukamandi-Subang

Blanco, H. and C.R. Lal. 2008. No-tillage and soil-profile carbon sequestration: An on-farm assessment. Soil Sci. Soc. Am. J. 27(3): 693-701.

Darung U, Mimbar SM, Syekhfani. 2001. Pengaruh Waktu Pemberian Kapur dan Pupuk Kandang terhadap Pertumbuhan dan Hasil Panen Kedelai pada Tanah Gambut Pedalaman Kalteng. Buletin Biosain. 1(2):

Ditjen Pangan Kementerian Pertanian R.I. 2010. Program Pembangunan Ditjen Pangan. Tahun 2010. Kementerian Pertanian RI. Jakarta.

Efendi, Halimursyadah, H.R. Simajunta. 2012. Respon Pertumbuhan dan Produksi Plasma. Nutfah Padi Lokal Aceh Terhadap Sistem Budidaya Aerob. J. Agrista. 16 (3): 114-121.

G. Y. Jayasinghe, Y. Tokashiki, M. Kitou \& K. Kinjo. 2010. Effect of Synthetic Soil Aggregates as a Soil Ameliorant to Enhance Properties of Problematic Gray ("Jahgaru") Soils in Okinawa, Japan. Communications in Soil Science and Plant Analysis, 41(5), 649-664.

Harsono A, Suryantini, Prihastuti, Sucahyono D, Sudarjo M. 2011. Efektifitas pupuk hayati Rhizobium toleran masam bentuk pelet pada kedelai di lahan masam. Dalam Sudaryanto (eds): Prosiding Seminar Hasil Penelitian Tanaman Aneka Kacang dan Umbi. Malang.

Hartatik, W. Sulaeman \& A. Kasno. 2007. Perubahan sifat kimia dan ameliorasi sawah bukan baru, lahan sawah bukan baru. Balai Besar Penelitian dan Pengembangan Sumberdaya Lahan Pertanian, Bogor.

Hartatik W, LR Widowati. 2006. Pupuk Kandang, Pupuk Organik dan pupuk hayati. Hlm 5289. Dalam RDM. Simanungkalit, DA. Suriadikarta, R. Saraswati, D. Setyorini, W. Hartatik (eds.). Pupuk organik dan Pupuk Hayati, Balai besar Penelitian dan Pengembangan Sumber Daya Lahan Pertanian. Bogor.

Jun Yu, Songnian Hu, and Jun Wang. 2002. A Draft Sequence of the Rice Genome (Oryza sativa L. ssp. indica). Science. 296:79-92.

Las, I. 2003. Peta perkembangan dan pemanfaatan varietas unggul padi. Balai Penelitian Tanaman Padi, Sukamandi.

Li-ping, L., Xiao-hua, L., Hong-bo, S., Zhao-Pu, L., Ya, T., Quan-suo, Z., \& Jun-qin, Z. 2015. Ameliorants improve saline-alkaline soils on a large scale in northern Jiangsu Province, China. Ecological Engineering, 81, 328-334.

Mohanty, S. 2013. Trends in global rice consumption. Rice Today (January-March):44-45.

Mulyani, A. dan M. Sarwani. 2013. Karakteristik dan Potensi Lahan Sub Optimal untuk Pengembangan Pertanian di Indonesia. Jurnal Sumberdaya Lahan No. 2 tahun 2013. Hlm 47-56. Balai Besar Litbang Sumberdaya Lahan Pertanian, Bogor.

Munir, M. 1996. Tanah-Tanah Utama Indonesia. Dunia Pustaka Jaya, Jakarta.

Muyassir. 2014. Efek Jarak Tanam, Umur Dan Jumlah Bibit Terhadap Hasil Padi Sawah (Oryza Sativa L.). J. Manajemen Sumberdaya Lahan. 1 (2): hal. 207-212.

Nath, T.N. 2013. The macronutrients status of long term tea cultivated soils in Dibugrah and Sivasgar Districts of Assam, India International Journal of Scientific Research. 2(5):273-275.

Neeraja C.N., A.S. Hariprasad, S. Malathi,\& E.A. Siddiq. 2005. Characterization of tall landraces of rice (Oryza sativa L.) using gene-derived simple. 
Nursyamsi, D., J.S. Adiningsih, Sholeh, dan Abdurachman Adimihardja.1996. Penggunaan bahan organik untuk meningkatkan efisiensi pupuk $\mathrm{N}$ dan produktivitas tanah Ultisols di Sitiung Sumber. J. TanahTropika (2): hal. 26-33.

Pangaribuan, D., dan H. Pujisiswanto. 2008. Pemanfaatan Kompos Jerami untuk Meningkatkan Produksi dan Kualitas Buah Tomat. Prosiding Seminar Nasional Sains dan Teknologi-II Universitas Lampung 7(1). Hal 6-8.

Prasetyo, B. H., dan Suriadikarta, D. A. 2006. Karakteristik Potensi Dan Teknologi Pengelolaan Tanah Ultisol Untuk Pengembangan Pertanian Lahan Kering di Indonesia. Balai Besar Penelitian dan Pengembangan Sumberdaya Lahan Pertanian Dan Pengembangan Sumberdaya Lahan Pertanian. Balai Penelitian Tanah. Bogor. Jurnal Litbang Pertanian.

Prayogi W.E. 2012. Ahli pangan: Indonesia dimitoskan tidak bisa ditanam gandum. www.finance.detik.com.

Reyes, L. 2013. Rice Facts: Trends in Global Rice Consumption. Rice Today. International Rice Research Institute Philipines, 12(1):44-45.

Soil Survey Staff. 1999. Keys to Soil Taxonomy. 10th Edition. United States Department of Agriculture (USDA), Washington, DC.

Subagyo, H., N. Suharta, dan A.B. Siswanto. 2004. Tanah-tanah pertanian di Indonesia. Dalam A. Adimihardja, L.I. Amien, F. Agus, D. Djaenudin (Ed.). Sumberdaya Lahan Indonesia dan Pengelolaannya. Pusat Penelitian dan Pengembangan Tanah dan Agroklimat, Bogor.

Subandi. 2007. Teknologi produksi dan strategi pengembangan. Jurnal Iptek Tanaman Pangan Vol. 2 (1).

Suharta, N. dan B.H. Prasetyo. 2008. Susunan mineral dan sifat fisiko-kimia tanah bervegetasi hutan dari batuan sedimen masam di Provinsi Riau. Jurnal Tanah dan Iklim 28:1-14.

Suparyono dan Agus Setyono. 1993. Padi. Jakarta: Penebar Swadaya. Hal: 118.

Suprapto, A., 2002. Land and water resources development in Indonesia dalam FAO Investment in Land and Water. Proceedings of the Regional Consultation.

Surowinoto, S. 1982. Budidaya Tanaman Padi. Jurusan Agronomi Faperta IPB. Bogor. Hal: 56-58.

Sobrizal. 2016. Potensi Pemuliaan Mutasiuntuk Perbaikan Varietas Padi Lokal Indonesia. J. Ilmiah Aplikasi Isotop dan Radiasi. 12 (1): hal.23-35

Tjitrosoepomo, G. 2007. Taksonomi Tumbuhan. Gadjah Mada University Press, Yogyakarta.

Utama, H.Z. 2015. Budidaya Padi Pada Lahan Marjinal, Kiat Meningkatkan Produksi Padi. Andi Offset. Yogyakarta.

Waty, R., Muyassir, Syamaun, \& Chairunnas. 2014. Pemupukan NPK dan Residu Biochar terhadap Pertumbuhan dan Hasil pai sawah (Oryza sativa L) Musim Tanam Kedua. J. Manajemen Sumberdaya Lahan. 3 (1): hal. 383-389

Yatno, E., M. Hikmat, N. Suharta, dan B.H. Prasetyo. 2000. Plinthudults di KalimantanSelatan: Sifat morfologi, fisika, mineralogi, dan kimianya. hlm. 353-366. Prosiding Seminar Nasional Reorientasi Pendayagunaan Sumberdaya Tanah, Iklim, dan Pupuk. Pusat Penelitian dan Pengembangan Tanah dan Agroklimat, Bogor. 